\title{
A Chronological Study of Entrepreneuriship and Ownership in Mexican Governance Since 1982
}

\author{
José G. Vargas-Hernández \\ Profesor Investigador miembro del Sistema Nacional de Investigadores \\ Departamento de Mercadotecnia y Negocios Internacionales \\ Centro Universitario de Ciencias Económico Administrativas Universidad de Guadalajara \\ Periférico Norte 799 Edificio G-306, Zapopan, Jalisco C.P. 45100; México
}

Tel: 52-33-3770-3343 Ext 5097

E-mail: josevargas@cucea.udg.mx, jgvh0811@yahoo.com, jvargas2006@gmail.com

\author{
Mohammad Reza Noruzi \\ Executive Master Business Administration, EMBA \\ Islamic Azad University, Bonab, Iran \\ Young Researchers Club Member, Bonab, Iran \\ E-mail: mr.noruzi@yahoo.com
}

\begin{abstract}
After the 1982 crisis, Mexico entered into a painful, distressful, and controversial period of state restructuring. Beginning in the 1982, and led by President Miguel de la Madrid (1982-88), Mexico began to withdraw the state from direct involvement in economic affairs adopting economic policies of privatization of state assets and reduction in state provisions for social security. Under the influence of the Institutional Revolutionary Party (PRI), the Mexican State initiated economic modernization and participation in the globalization processes, as a response to the trends of the economic globalization of markets, and the technological revolution that began during the last two decades of the past century. This paper aims to analyze the chronological study of entrepreneuriship and ownership in Mexican governance since 1982
\end{abstract}

Keywords: Ownership, Change in ownership, Entrepreneurial state, Mexico, State of entrepreneurs

\section{Introduction: Ownership of the Mexican entrepreneurial}

Under the new economic policies of this structural adjustment reform, one important that changed ownership was the privatization of state-owned enterprises and banks. Mexico's privatization program began with the divestiture of state-owned companies, starting with small and medium sized and later turning to companies that required internal reorganization before being privatized. State-owned enterprises were sold to private investors, who expanded and upgraded services (Savitsky and Burki, 1999). The state-owned firms had been purchased by the larger domestic and foreign business conglomerates. The economic liberalization in Mexico in 1987-94 attracted a great deal of foreign capital precipitating a massive private lending boom. In the 1990s, while the role of the Mexican state was scaled back through the privatization and liberalization processes that eased the fiscal pressures, the private sector was playing a larger role in driving the capital markets. Privatization in Mexico attracted large inflows of foreign direct investment in expansion of the economy, although the flow of FDI into Mexico by sale of public assets, sale of private assets and new assets, showed that a growing share of FDI flows to Mexico was invested in new assets.

Mexican economic nationalism emerged as a result of promoting public and private Mexican capital to avoid foreign investment, mainly by the United States. The Mexican State was characterized by an historical distrust of capitalism and a belief in the ability of the government to intervene and regulate economic affairs through its explicit constitutional mandate (Grier and Grier, 2000: p. 245). from the 1930s and until the 1970s a model of import substitution industrialization (ISI) favored private Mexican investments and was also believed to benefit the people. The Mexican public sector enlarged the number of publicly owned corporations. In 1982 state owned enterprises produced 14 percent of gross national product (GNP), received net transfers and equal subsidies of 12.7 percent of GNP and represented 38 percent of investment in fixed capital.

The crash of the Mexican economy in 1982, left the country defaulted on foreign-debt payments, investors fled Mexico, and companies traded for cents on the peso. Hundred of thousands of micro, small and medium sized 
firms went bankrupt in the 1980s because of stagnant domestic demand, rising inflation, greater foreign competition, and higher credit costs (Davis, 1992, Vega, 1991). The entrepreneurs founded the Consejo Coordinador Empresarial (Entrepreneurial Coordinating Council) (ECC) to defend their interests from State intervention. Mexican businesses that served foreign markets were more financially healthy than the domestically-oriented ones in the 1980s. In 1982 in the middle of a general economic crisis caused by a fall in oil prices, President López Portillo (1982-88) nationalized the banking system, devalued the peso, and increased interest rates. The country defaulted on practically all payments causing a fracture in the pact between the State and the ECC. The crisis of 1982 was also meaningful as the crisis of hegemony, which was present in the old alliance between the State and ECC who represented national capital and were the direct beneficiaries of economic policies based on the import substitution model.

\section{Ownership transition of the Mexican State: Presidentialist neoliberal restructuring}

Under the pretext of cleaning up the economy, the Mexican State privatized strategic enterprises of the public sector, most of which were acquired by foreign investors, who had already penetrated all economic sectors. The high concentration of capital in a few corporations through the privatization process of public enterprises unleashed phenomena of political privatization and foreign investors could penetrate in most eras of the country by having much more share in enterprises. The privatization process marked a new turn in the relationships of co-operation and conflict between the State/government/Institutional Revolutionary Party (PRI) -business in Mexico. Mexico has aggressively implemented privatization as the economic policy central to its market reforms. Relationships between the state and firms have taken a new turn since the 1980s, as a result of an aggressive privatization program of several economic sectors such as the banking and financial sector, telecommunications, airlines, etc. The Mexican government's overall package of stabilization and structural adjustment reforms transformed the inter-governmental relationships and the relationships between firms, communities, new social movements and the three levels of government, federal, state and local.

The reinvention of the new Mexican State was initiated under the impulse of an intervening state with a strong neoliberal technocrat orientation, to the benefit of the owners of capital. The process was based on neocorporatist negotiation between entrepreneurs and government, and built on mutual interests and compromise. The changes included: economic reorganization; national market openness; elimination of commercial barriers; elimination of price controls and subsidies; privatization of public enterprises and state property; reduction of social policy expenses; free money exchange, and also wide political reforms and administrative modernization. It abandoned the import substitution model and called economic intervention in the state into question.

It is possible to establish with certainty to what extent political considerations drove the government's approach to privatization in Mexico. The change in ownership of large-scale public enterprises was commenced after internal evaluations and under the management of commercial banks acting as the government's agents. Even the World Bank Mexico (2007) documented pernicious presence of special interests is visible in the economic arena as well. Many Mexicans hoped privatization would create competition and drive prices down drastically, but it hasn't happened (Mehta, 2007).

The main thrust of the reforms encouraged in Mexico was the development of a competitive, broad-based export sector of nontraditional goods. Mexico joined the General Agreement on Trade and Tariffs (GATT) in 1986 and became an exporter of manufactured goods. The strategies adopted for the design of the Mexican State, as it was for other states, was reduction of state structures and facilities, privatization of state owned enterprises, and economic deregulation. Private ownership, as opposed to public ownership, is more conducive to improving the scope for competition, although the privatization of public assets does not necessarily increase efficiency and innovation.

With the introduction of these reforms the Mexican State began to lose its capacity to function as a nation, although the State maintained that the reforms benefited the owners of capital. These reforms to the structure of the Mexican State's apparatus make sense out of its transition and change from the welfare state model toward a neoliberal state model (Nayyar, 2006). This transition and change are understood as forms of behavior, loss of centrality in politics, loss in the ability to build a sense citizenship, transformation of politics into one electoral technique, and an increase in market problems. Also, a loss of ethics and principles in the work of politicians and political institutions evidently appeared in Mexico during the government of Miguel de la Madrid (1982-88), continued with Salinas de Gortari (1988-94), and also with Zedillo (1994-2000), later with Fox (2000-2006) and will continue with Calderón (2006-2012). See table 1.

Insert Table 1 Here 
The new business elites which represent a new generation of private sector leadership took an active part in the auctioning off of the many state-owned enterprises during the Salinas de Gortari administration. The principal strategy of Salinas de Gortari was privatization which he accelerated to implement.

The PRI responded to the allegations of electoral fraud in 1988 by moving toward a very limited form of shared power with the PAN and accentuating the dependence on private investment in the domestic economy by promoting the export-oriented interests and attracting coalition partners. Salinas deepened neoliberal reforms and most of the public enterprises were liquidated, economic openness was accelerated, and several free commerce agreements were signed. Under the North America Free Trade Agreement (NAFTA), the Mexican government adopted the philosophy that foreign ownership brings economic growth and social development.

The factors that shifted the internal structure of the private sector in México against protectionists and towards free trade interests were the international

context, the domestic economy and government policy. The North American Free Trade Agreement represents the incorporation of big business and private sector interests into the trade policy making apparatus through the Coordinating Council of Foreign Trade Business Organizations (COECE). The Mexican government was extremely concerned with attracting the large firms' mobile investment resources (Arriola 1994, Blanco 1994) and many had been involved to increase the private sector's participation through organizations eager to play more active roles in trade policy making (Thacker, 1998). The activism of the Mexican State during Salinas' mandate allowed the transfer of public enterprise to financial groups which were determined to maintain links of political complicity. Most of the economic reforms under the Salinas administration happened in the second half of the sexenio.

In 1982, 934 state-owned companies of a total of 1,155 were divested, leaving only 221 managed by the Mexican State. Between 1983 and 1993, The Mexican state divested itself of some 942 state-owned entities, 215 state-owned enterprises were sold off, and another 594 were closed, merged or transferred by the state (Bazdresch and Elizondo 1993. 51). Since 1989, and until 1994, the private development of public infrastructure, as a variation of privatization, has launched thirty-two build-operate-transfer projects with 28 more on the drawing boards, in areas such as highways, ports, power generation, airports and water projects, as it was reported by Randolph (1994).

Mexico ranked second in privatization in Latin America during the decade of the nineties when the government transferred to private corporations assets that amounted to 31,458 million dollars, which represented 20.4 percent of the total sales of state owned enterprises in Latin America. Privatization reached 3,160 million dollars in 1990, increased to 11,289 million in 1991, and totaled 6,924 million dollars in 1992. By June of 1992, the Mexican government had privatized 361 out of approximately 1,200 enterprises owned by the state. By 1993 only 213 remained in state hands (Garrido 1993, 36). Privatization during 1993 represented 2,131 million dollars.

In 1993 legislation was enacted authorizing the private management of ports. Concessions granted for construction of toll roads through private resources covered 2,400 miles of roadway (Corona, 1993). Randolph (1994) reported privatization sales until the year 1994 have netted the government $\$ 20.9$ billion. In 1996, public and private investments in Mexico were kept under the levels of the seventies and eighties. In 1996 it increased to 1,526 million dollars, in 1997 to 4, 496 million, and in 1998 decreased to 999 million dollars. A report from the World Bank states that between 1990 and 1998 privatization of public enterprises reached a total amount of 154,225 million dollars, an amount only less than the balance of the total external debt of Mexico which in 1998 was of 159,959 million dollars. The year in which the state recorded most privatization was 1991 with a total of 11,289 million dollars, while in 1998 Mexico the lowest was 999 million dollars.

\section{Change of the party in power: The Mexican State of entrepreneurs in the new PAN - presidentialist period}

In Mexico the XXI century began with the new paradigm of the entrepreneur and manager government. PAN's charismatic leader, Vincente Fox, won the election for the Presidency in the year 2000. More than continuity, the pattern of neoliberalism increased with Fox's rise to the presidency of Mexico. He represents a third movement of the neoliberal economy begun by Salinas. Nevertheless, the technocrats were hit politically by the entrepreneurs and managers. The new political class, which mainly emerged from the local organizations of small and medium entrepreneurs in the North, wanted to liberate the country from the corruption and clientelism of the State party. The Entrepreneurial State was dismantled in the rise to power of the technocratic economists. With a manager-like President in Mexico, the Mexican State has become a State of Entrepreneurs and Managers that treat democracy like good business, such the Coca-colaification of Mexico in reference to the managerial 
antecedents of Fox's transnational government. Fox the governing of Mexico was not the same thing as managing Coca Cola, but his managerial experience could help him to make decisions. Fox's rise to power, coincides with the consolidation of a concentration process, an economic oligopolization, and political centralization of decision-making (Fazio, 2000a). Fox's ascendancy to the Presidency of Mexico, according to Krauze (mentioned by Fazio, 2000b) resulted in a direct, immediate switch to managerial power. Wines of new marketing in old wineskins of caudillism... a caudillism plebiscitary with messianic edges, very dangerous in a country like ours that finds the separation between the church and the State difficult. Fox is the first manager president to arise out of the local elite from the center of the country. He represents the "electoralist stream" of the entrepreneurial and managerial elite in PAN and especially the stream dominated by the faction from the northern states or "Monterey Group". The large outward-oriented, northern business groups housed in Monterrey have adapted a new corporate culture. The emerging new business elite are characterized by a corporate business culture and hierarchical structure, oriented toward external markets, and multinationally-linked through alliances and joint ventures.

The arrival of the entrepreneurs and managers to the Mexican State meant the displacement of politicians with formal power. In other words, what changed was formal power, because the real power remains unalterable. The Mexican Council of Businessmen stopped being a pressure group in the face of the power of the State and became instead the representatives of the entrepreneurs in the federal government who determine national economic and political decisions. That is to say, the political power taken by the conservative groups that held hegemonic, economic power and the national neo-oligarchy was subordinated to the interests of transnational capitalism exercising a new governance strategy. This strategy allowed them to dominate and directly control the means for achieving their maximum benefit (efficiency), without necessarily appealing to the mediation of a political class that was highly paid for the mediation of the arrangements for production factors. This is the case between capital and work, for example. However, in humanity's history, the achievement of efficiency has not brought social justice.

The State's entrepreneurs focus considers citizens as clients whom it must satisfy with services of absolute quality. The president exchanged the word client for that of citizen, with a vision on the one hand, for example, that it is inappropriate to promote the policy of indigenous community development. Disrespectfully, Fox has called the indigenous people "vocho, changarro and tele" in response to their centuries of rebellions against the capitalist system for the injustices perpetrated against them. To neoliberalism centered in the forces of the market, the indigenous peoples are not consumers. Therefore, they are disposable and, in the best case scenario, a population to be integrated or assimilated into the lowest ranks of the work force without rights and subordinate to capital, as exemplified by the proposal made during Fox's campaign to train them to be "the foreigners' gardeners". Political analysts agree that his proposals have been contradictory, sometimes retrograde, sometimes hopeful, but always lacking a coherence that would make the program complete.

The new State of entrepreneurs administers the existing order efficiently to guarantee transnational global capital that the best conditions for investments exist in Mexico. The general coordinator of economic affairs in the transition team guaranteed "zero discrimination" for Mexican entrepreneurs. On the other hand, the leader of one of the most powerful organizations of entrepreneurs warned that Fox's government would be friendlier to the production sector. Fox has a clear vision of the needs of a company, so he can create wealth and more work sources (Becerril, 2000). On the other hand, the entrepreneurs have declared (Becerril, 2000) they were convinced that the new government would be "friendlier".

\section{Changes in ownership: from State owned enterprises to private monopolies}

Under the Salinas administration, the economic reforms were more aggressive although not always resulted in a more competitive economic sectors structure or in a more equitable distribution of economic benefits. The privatization program was conceived originally to balance the fiscal budget by generating income and reducing subsidies but soon was evident the necessity to improve economic competitiveness. The change in leadership created high expectancies for privatization of more state owned industries in Mexico. However, privatization as an economic policy in Mexico meant a mere change of ownership from public monopolies into private ones, without an effective regulatory framework in place and strong regulatory agencies capable of enforcing more competitive conditions (World Bank Mexico, 2007).

State-owned companies that had changed in ownership under the privatization program covered all the financial and banking system, the main two airlines (Aeromexico and Mexicana), the telephone company (Telmex), steel, 
insurance, hotels, mines, shipbuilding, gas stations, movie studios, manufacturing, airports, railways, etc. The new government of Mexico plans to privatize the energy sector, oil and electrical industries.

\section{Change in ownership in the telecommunications sector}

The privatization of the telecommunications sector merely replaced public monopolies with private monopolies, such as the case of Telmex, the Telephone Company, and Televisión Azteca, one of the two larger television broadcasters. Mexico's telecommunications company was a state-owned monopoly which under unclear procedure was sold off to Carlos Slim who bought 20 percent of Telmex's stock and 51 percent of its voting options (Bazdresch and Elizondo 1993, 59).

Clouding the deal was the fact that Slim was a huge contributor to Carlos Salinas de Gortari's PRI party. When the government put the state-owned telephone company, Teléfonos de México, up for sale, Slim partnered with AT\&T and France Télécom to buy $20 \%$ of the company in late 1990 for about $\$ 2$ billion. The newly privatized telephone company got seven-year guarantee of monopoly status. When Slim purchased the telephone company, he was in an extremely close and advantageous relationship with the Salinas government.

Telmex privatization shows the political dimension of Salinas' privatization strategy. Salinas favored inclusion of the Mexican control clause in the concession of Telmex because of his interest in developing strong Mexican business groups (Murillo, 2001). To accommodate labor interests in favor of friendly unions and following a classic corporatist style of "back door" negotiations, the government agreed to give away some ownership concessions to the labor union Sindicato de Telefonistas de la República Mexicana (STRM). Government and the management promised not to dismiss any existing employee due to privatization among other benefits (World Bank Mexico, 2007).

The economic effects of the "liberalization" of the telecommunications sector and more specifically, privatization of the state-owned Telmex, have created legal barriers to entry in the concession title and "retained the company as a vertically integrated monopoly, in the place of the former public monopoly (World Bank Mexico, 2007). In 1995, the government introduced the Federal Telecommunications Law that created a regulatory agency the Commission Federal de Telecomunicaciones (COFETEL), the Telecommunications Federal Commission, and restricted foreign ownership to $49 \%$ and applied to all operators except IUSACELL sold to a Canadian investor.

Nowadays, Slim's Teléfonos de México controls 92\% of the country's phone lines, and his América Móvil wireless service has a 70\% market share. Rates for monthly service and residential phone hookups are among the highest in the developing world. It has been already said that Slim is richest man of the World. With nearly US\$60b, Mexican telecoms tycoon Carlos Slim is heading the Forbes list of world's wealthiest overtaking Microsoft founder Bill Gates for the title of the world's richest person, as it has been reported by Fortune magazine. His family's holdings represent more than 5\% of Mexico's 2006 gross domestic product.

George W. Grayson (2007), coined the term "Slimlandia" to describe the entrenchment of the Slim family's companies in the daily life of Mexicans. Slim-controlled companies make up one-third of the $\$ 422$ billion Mexican Bolsa, or stock exchange (Mehta, 2007). Family ownership tends to be even more prevalent in other large business groups in México, where the interests of the owners and the firm are indistinguishable, financial accounts are frequently intermingled and there is not any need to be accountable to outsider shareholders.

The stock restrictions of Mexican companies keep the ownership with those that are directly involved in the success of the business. To protect against dilution and decreasing the ownership percentage of stockholders when the company issues stock, investors require the company to give them structural anti-dilution protection, and preemptive rights. To maintain control over the company's ownership, it is necessary to keep the mechanism of a preemptive right (derecho de preferencia) that the Mexican law grants to all stockholders of a company to purchase their pro rata portion of any new stock issues. This mechanism is designed to protect stockholders from having their ownership percentage in the company diluted or decreased.

\section{Change in ownership of the banking sector}

The banking sector illustrates well the symbiotic development between the government and the economic elite of Mexico. Nationalization of the banking system was the main event that provoked the rupture between the political and entrepreneurial hegemonic blocks and their representatives, the politicians and government officials from the party of the State and the factions that controlled capital. Nationalization of the banks in 1982 temporarily restricted national capital markets (Maxfield, 1990). With nationalization of the banking system Mexican capitalists, who felt betrayed, broke their alliance with the political bureaucracy and designed a strategy for their own re-constitution. 
The banking policies implemented by de la Madrid (1982-1988), Salinas de Gortari (1988-94) and Zedillo (1994-2000) led and strengthened re-privatization of nationalized banks purchased by the emerging group of business elites owners of business conglomerates financially-linked to foreign investors, owners of the largest business groups tied to private financial institutions who had made fortunes on the parallel financial markets and more amenable to free trade. As it is said by Fazio (2000a), they were living in one tortuous lover relationship of subterranean blurred tides, intense shady deals, and complicity networking.

The old owners of the banks were indemnified by 1986. One third of the bank stocks were sold to the private sector, non bank financial operations such as stock brokerages, insurance, guarantee and mortgage companies were re-privatized (Hernández Rodríguez, 1986). The banking policy of limited competition allowed the banks to engage in non competitive behavior, erected entry barriers, holding portfolios composed of stocks and loans to other firms owned by their own directors. Private financial operations grew rapidly in an environment of volatile market and credit only accessible to the largest corporations on the Mexican stock exchange (Maxfield, 1989).

In 1991, when bank privatization began, four banks controlled 70 percent of total bank assets (Haber, 2005). The re-privatization of bank strengthened private capital markets and placed control of the largest banks into the hands of a small group of owners who made their fortunes in the parallel markets of the 1980s (Elizondo, 1993). After the 1991-92 privatization banks were allowed to "disguise some of the poorly performing loans cultivated the ground for the eventual collapse in December 1994, when the peso devalued massively (World Bank Mexico, 2007). The liberalization and privatization of the financial sector the late 1980s in México triggered a lending boom. The bank credit to the private sector soared up to 40\% of GDP in 1994 from less than $10 \%$ five years earlier (Savitsky and Burki, 1999).

The net interest margin as an indicator of banking efficiency in Mexico did not decrease after the bank privatization in 1992, meaning that a higher margin indicates lower efficiency because a higher spread on deposit and lending (González Anaya and Marrufo, 2001). The acquisition of banks was set up specifically for the privatization undertaken mostly by groups led by new entrepreneurs who arose from the securities business (World Bank Mexico, 2007).

Economic liberalization led to privatize national and state banks, including the largest banks - Banamex, Bancomer, and Serfin - which were bought by Mexican investors. Two years after the privatization of its banking system, in December 1994, Mexico was forced to devalue its peso which set off a macroeconomic crisis characterized by increased exchange rate volatility, further devaluation of the peso and was followed by a financial sector crisis and bailout. In the wake of financial liberalization in Mexico and with insufficient regulatory agencies occurred the tequila crisis, which prompted unsustainable lending booms driven largely by the private sector. The financial crisis of December 1994 had hammered the Mexican banks pushing them to accept foreign investments to bolster their equity position.

The new structure of State debt, during the Mexican crisis of 1994-95, has been studied widely by most scholars in order to understand the way in which financial markets, governments, and multilateral institutions respond to the new questions of governance. The Mexican crisis raised the problem of sustaining fixed exchange rates in an environment of high mobility of international capital. Mexico did not recover because its weak financial system was strengthened through the intervention of the International Monetary Fund (IMF). The pack of credits given to Mexico in 1995 by the IMF was a reward for banking with more risk. Better prudential control of domestic banks may be prone to inefficient rents demanded by powerful local constituencies (Agénor 2001). While more governments of other countries lend to Mexico, their banks have more security to cover their loans.

In reality, the privatization of the banking system into financial groups emerged from the "steam" and complicity among investors and politicians who took advantage of international organizational finances channeled to rescue Mexico from the debt crisis. However, their differences in crisis management took them into highly indebted economies, which had the opportunity of transferring charges to society. The Mexican government supported the weak banks taking over the bad loans in 1997 which were sold off in October 1999. Lamentable as it is foreseeable the present administration will leave an inheritance to the next government of a greatly compromised public finance and an even greater inability to respond to the reasonable demands of the people. Zedillo's inheritance amounts to more than two billion dollars (million, million dollars) in public debt, including the wasted debt of the Institute for the Protection of Bank Savings or Instituto para la Protección del Ahorro Bancario (IPAB).

Implementation of economic policies aimed to ensure the increasingly liberalized financial system, required the introduction of neoliberal measures since December 1998 when the Mexican Congress approved the financial reform. The liberalization of the foreign investment rules is a clear indication of the ongoing investment 
environment with a very favorable attitude that the government has taken towards foreign investment. By December 1998 the three largest Mexican banks merged to larger foreign financial institutions or large portions of stock were acquired by foreign banks. In May 2000, Serfín was sold to Santander and Bancomer was bought by Banco Bilbao Vizcaya (BBV) in June 2000. In July 2001, Citigroup took over Banamex in July 2001 and four months later, in November 2001, it announced layoffs of 7800 workers.

One of the items stood out as the single most important measure of financial liberalization to ease further constitutional barriers to foreign ownership in the Mexican financial system to allow foreign investors, commercial banks and financial holding companies to own up to $100 \%$ of common stock. Foreign ownership of Mexican companies was limited to 49 percent. México enacted new regulations aimed to relax the restrictions on foreign investment. Today, under these new regulations, foreign investor's can own up to 100 percent of any kind of enterprises and business, without prior authorization from the Foreign Investment commission, without requirements to engage a Mexican investment partner.

Following the arguments of Dymski (2002) and Crystal, Dages, and Goldberg (2002), on the basis of comparisons of foreign and domestic banking firms, the authors argue that acquisitions of Mexican domestics banks by megabanks provide another path to better governance, since implicitly megabanks are more efficient, more market-oriented, and regulated by more experienced national banking authorities. So providing maximum scope for the global expansion of first-world megabanks could, in this view, ensure universally higher welfare levels. Foreign banks accounted for 78 percent of all banking assets in 1999, 79.8 percent in 2000 and had reached almost $90 \%$ in 2007, leaving space only for one large bank Banorte and several small local banks. However, this argument has not been the case of Mexican situation where 90 percent of the local banks had been under process of acquisition. In fact, the opposite is the real case, banking services are quite expensive, decreasing the interests for deposits and credit is scarce with higher interest rates than before. The effects of financial crises and economic liberalization supported by Mexican government paved the way for foreign penetrations into Mexican banking and financial market, one of the most profitable for foreign banks operating because the expensive price for customer services.

\section{Change in land ownership}

An "ejido"(collective landholding) is a community with a unique system of land-ownership, land jointly owned by its members, the ejidatarios. Ownership and administration of an ejido, formed as the basic unit of agrarian reform policies as a response to the demand of land ownership during the Mexican Revolution (1910-1917) and had been entrenched to protect peasants' rights following the 1910-17 Revolution. After the Mexican Revolution, government broke up the large land holdings called "haciendas" held by the wealthy and powerful and the ejido system was created by a government decree.

Land ownership reform was fully implemented during the thirties under the regimen of a socialist president, Lázaro Cárdenas, in order to recover the land ownership which originally was owned by aboriginal people and later concentrated by the rich hacendados. The land was re-assigned in small parcels to indigenous communities in an ejido system. The ejido was legally vested in the communities of townships adapted from the Indian tradition of communal farming and were responsible for allocating cropland to individual ejido members the ejidatarios. Indigenous lands were hold either in the form of ejidos or as communal property, but vulnerable to land grabs by rural bosses and large landowners, called Caciques, who obtained protection from powerful political figures or agrarian officials (Americas Watch, 1993). Ejidos had occupied half of Mexico's arable land which had shrinking plot size and suffered from a lack of credit.

The economic and legal reforms enacted as part of Mexico's 'Reform of the Countryside', began in the late 1980s. Under the policy of modernization aimed to integrate rural Mexico into the global economy, legal, economic, and institutional reforms set the framework for changes and modifications to the Foreign Investment Laws. These changes allowed up to $100 \%$ of foreign ownership of industries in Mexico and changes in the ejido land-reform program has lead to the transfer of both ownership and management of lands throughout the region from ejido back to the private sector (Lewis 2002, Luers 2003).

Institutional reforms promulgated in the 1980s and 1990s by the Mexican government and the consequent economic policy changes during the 1990s had driven rapidly changes in the use and management of lands. One important result has been the transfer of lands from the ejido to private sector. Foreigners were able to acquire land ownership through the title held by a Mexican nominee. This was once true, but it is not longer so. After 1990, a group of government officials established the new conditions for land ownership in Mexico, which led to the modification of Article 27, of the Mexican Constitution, and various other laws corresponding to this matter. 
In late 1991, Salinas began the reform of Mexico's land ownership system of 28,000 "ejidos", or communal farms, in another move that challenged entrenched constituencies.

The main argument for freeing up land sales was that economic and commercial "modernization" of agriculture was necessary if Mexican producers were to compete with cheap food imports, especially of U.S. corn and beans, entering under the North American Free Trade Agreement (NAFTA). However, modernization and liberalization economic policies on energy and land ownership had provoked opposition to NAFTA which establish free trade in agricultural products, including the staples corn and beans. The battle cry of Zapata, "Land and liberty", tierra y libertad was the backdrop to the 1994 "Zapatista" army's denunciation of NAFTA as locking in a policy of agricultural commercialization only favorable and benefiting the large agricultural producers and not the smaller land owners producers.

Article 27 of the constitution was revised and a new Agrarian Law passed. Article 27 of the Mexican Constitution grants Mexican ownership of the land and water within its territory and stipulates that Mexico shall oversee the transfer of ownership rights to individuals, by creating private property. Amendment to Article 27 of Mexico's Constitution legalized the rental and sale of previously inalienable ejido land. The change in land ownership under the reforms allowed ejidatarios and communal farmers to sell and rent farm land to both domestic and foreign investors. A process was enacted whereby certain tracts of ejido land were regularized and held up for sale for foreigners, who were able to acquire land ownership. It also created programs and institutions to officially certify ejido members' land rights. However, at the same time, members of ejidos (ejidatarios) and communal lands had to cope with reduced subsidies to agriculture and low prices in harvested products.

Amendments to Constitutional Article 27 formally adopted in March 1992 allowed privatized the ejido system of land distribution and investments in the Mexican countryside. The 1992 Agrarian Law allows for the owner of property rights within the Ejido to sell or lease the property rights to a non-Ejido member. All foreigners holding land property own their land under the fideicomiso system, a trust agreement between the purchasers of land with a bank, the Mexican equivalent of clear title land. The foreign purchaser enters into an agreement to give in trust the title land to a chartered bank whereby he becomes the beneficiary of that trust set for fifty years whence there are renewable.

These reforms supported new economic policies which meant the end of the Mexican state support agricultural activities. In rural areas of Mexico, neoliberal macroeconomic reforms fully implemented eliminated subsidies for agricultural inputs and most food, credit and technical assistances for agriculture, price support for basic grains and eliminated the land reform.

The neoliberal economic policies and land reforms implemented under the Salinas administration removed constitutional restrictions of the ejido land to be kept in community ownership allowing the land of the ejido to be leased and sold to private owners, reversing the trend to reach land concentration by new land-owners. Also, the Mexican Foreign Investment Law, ratified on December 28, 1993, allows a foreigner or foreign corporation to obtain the rights of land ownership through a fiduciary trust or beneficiary trust (Fideicomiso). A Mexican corporation which, under certain conditions, can be $100 \%$ foreign-owned can purchase non-residential property. Foreign investment is a major part of the Mexican economy, because land ownership in Mexico is very stable.

Change of land ownership, from ejidal and communal to private land ownership is now being concentrated by the new land-owners who generally grant the sharecropper use to peasants in return of one-half of the harvest (Crummet, 2001). Changes in Article 27 that allowed ejido land to be rented and sold resulted in significant alteration of ownership patterns and out migration. The change in ownership of the ejido land raised landlessness and rural inequalities becoming much worse, as millions of farmers and peasants were forced off the land when were unable to compete after import licenses were removed and all tariffs and import quotas are being gradually phased out the North American Free Trade Agreement (NAFTA) (Schulz and Wager, 1995).

On a daily basis, thousands of hectares of land are being removed from the Ejidos, and its property is being removed from federal control by the National Agrarian Registry and added to the public land registry in order to facilitate it to be sold or leased. Foreigners had been leasing properties from landowners in Mexico for many years, but with the recent change in ownership rules, a higher percentage of foreigners are buying real estate. Since 1917, article 27 of the Mexican Constitution prohibited direct ownership of real estate by foreigners in what had come to be known as the 'restricted zone' which encompassed all land located within 100 kilometers (about 62 miles) of any Mexican border, and 50 kilometers (about 31 miles) of any Mexican coastline.

Originally the 'restricted zone' was created to protect Mexico from foreign invasion. The real estate market in Mexico has taken huge strides during the last 10 years, under new real estate ownership tools that provide a high 
level of confidence for out of country buyers, and thus, offering thousands of miles of coastline for the development of beachfront properties. President Fox worked to make affordable financing available as a tool for foreign. The result is clear: What is emerging is a dual agricultural economy. Poor peasants do not own the land and have to sharecrop with the land-owners, and owners of small plots of land who work their land, both live at the level of self consumption.

However, the owners of large parcels of land can find the way to produce more export oriented crops. The concentration of land ownership in irrigation districts and most productive dry land agricultural regions in the hands of large agro-industrial groups is contributing to the impoverishment of peasantry. In order words, this dual agricultural economy is creating more poverty in the countryside while the owners of large land plots are becoming wealthier. The land tenure law changes lead to changes in ownership increases the vulnerability of the ejido population. The "inefficient" subsistence farmers became "surplus" faster, and were forced off the land to immigrate to United Sates, to enter into illegal activities related to drug production and distribution or to swell the ranks of the poor in already overcrowded and polluted large cities.

Lewis (2002) analyses reactions and responses to the 1992 amendment to Article 27 of Mexico's Constitution, using the findings of a 1999 case study of ejidos in the Yaqui Valley, Sonora, a prominent agricultural region of northwest Mexico. Lewis (2002:401) concludes that "the complex of economic and legal reforms - combined with the specificities of Sonoran agriculture - has generated a visible change in ejidos with respect to land operation, setting the stage for an accelerated shift towards the privatization of agricultural land in northern Mexico". The resulting insecurity and confusion in the country side of Mexico after the ejido land reform have fueled discontent throughout rural Mexico, providing the Zapatistas with a base of support from which to launch their rebellion (Schulz and Wager, 1995).

\section{Change in ownership in other important economic sectors}

Aeroméxico was declared bankrupt by the government in October 1988 and acquired by Aerovías de México. Also in 1988 Mexicana was privatized but government kept $40 \%$ of the capital. After privatization and deregulation of the airline industry, in 1993 Aeroméxico's acquisition of a 55 percent ownership stake in Mexicana, the two larger carriers merged escaping antitrust enforcement and consolidated taking control of more that two thirds of the domestic market for air travel and agreed to coordinate fares, and share ground services and crews. Finally, until 1995 the privatization process of Mexicana was completed.

\section{Change of ownership of the two jewels of the crown}

Business groups were privileged by the Fox presidency obtaining more political influence in the policy making process. They requested options for participation in the investing in the energy sector (electricity and secondary petrochemical). Fox continued implementing the reforms expecting to attract private and foreign investors to the energy sector. It was clear that Fox governed the Mexican State with a focus on the New Public Management, as if Mexico was a corporation: Mexico, CORP. which gives the petrochemical and electric sectors to transnational global capital.

PRI legislators refused to support the privatization process of PEMEX, the state-owned Mexican Oil Company when they agreed to eliminate the proposal to restructure the board by placing independent experts "free of conflicts of interest". A recalcitrant oppositional congress to change of ownership of the energy sector was a factor that contributed to Fox's failure to advance needed legislative reforms associated with electricity, natural gas and other energy issues, and it seems that Calderon (2006-2012), the President successor of Fox (2000-2006) will run the same luck than he had when he was the Minister of Energy. However, the Fox administration became embroiled in an ideological debate between privatization advocates and proponents of Mexican state control over the energy sector, Pemex and state electrical companies (Shields, 2005). Lopez Obrador, the political candidate to the Presidency of Mexico by the leftist PRD, who was defeated by Calderon under serious allegations of fraud in the 2006 elections, had promised if he became President, to pledge to modernize Mexico's energy sector by boosting spending on Pemex, the state oil company, and reducing Mexico's dependency of technological assistance from foreigners. Mexican voters' were unsure whether privatization of the energy sector was good for the patrimony of Mexico. The reforms to politically win passage in congress they needed to comply with demands for continued sovereign ownership and control over crude oil and gas.

Denationalization and privatization of the Mexican Oil Company, Petróleos Mexicanos (PEMEX) and the Federal Electricity Comission (Comisión Federal de Electricidad or CFE) is happening rapidly with the support of administrative procedures, although they are the most sensitive because they are considered as strategic industries for development and protected by Mexico's Constitution. Mexican government agreed in 1989 to open "secondary" petrochemicals to private sector investments under a cooperative program with PEMEX increasing 
its privatization de facto. However, nowadays, Mexican oil officials are awarding more "integral service contracts," over almost every aspect of a project to a contractor except ownership of the underlying resources, although laws against foreign ownership of oil and gas resources are still enforced. These actions explain the deregulation and privatization programs in the strategic energy sector.

\section{Re-assessing change of ownership in México}

The benefits of privatization have not yet been evident to the Mexican people even though defenders try to demonstrate the opposite. According to data provided by the former President of Mexico, advocator and implementer of the privatization program, Salinas de Gortari (1988-94), privatization reduced budget expenditures to finance social programs thus preventing a fiscal deficit. However, the effects have not been satisfactory over all. Programs of privatization in Mexico have reduced employment by half, while production has increased 54.3 percent with a significant reduction in investment. A study by Galal et al (1992) analyzed the after-privatization performance of twelve companies in different countries, including Mexico, and documented an increase of 26 percent in profits in eleven cases but an increase of benefits to workers in only three of the cases.

When the economic pattern that has been followed up to this point in Mexico is able to generate growth it will be accompanied by a growing concentration of income and an increase in poverty among the poorest strata. In a period in which the Mexican economy reached a peak over 18 consecutive trimesters of growth, the benefits went to a very reduced group of people: "only the crumbs fall down" states (González Amador and Castellanos, 2000). This resulted in a society with big contrasts in income distribution, where 20 million Mexicans (20 percent of the total population) live under conditions of extreme poverty, and more than 40 millions (40 percent of the total population) live below the line of poverty.

More than half of Mexicans old enough to work were employed in the informal sector of the economy. World Bank figures show that 42 million Mexicans have salary levels below twenty pesos daily, the equivalent of less than 2 dollars a day. With data from the United Nations organization, 64.5 percent of the population received insufficient wages to sustain minimum nutritional requirements; 40 percent of Mexican women live in homes with low income compared to 20 percent of Mexican men (Jiménez, 2000). During the period 1964-1981, the gross internal product per inhabitant rose to 7,776 dollars a year, with an average annual growth of 3.4 percent. However, after 1982 with the implementation of the Neoliberal State model in Mexico, the growth of the gross internal product fell. For the period of the Neoliberal State, which lasted from 1982 to 2007, the gross internal product per inhabitant only grew on the average of 0.3 percent yearly.

The National Survey of Income-Expense in the Households, carried out by the National Institute of Statistic, Geography and Informatics (INEGI) in the year 2000, reports that the generation of wealth increased in the last six years, but the distribution of the wealth became more inequitable, with alarming levels of deterioration. In Mexico 38.11 percent of national income is concentrated in 10 percent of the homes. At the other end, 10 percent of the poorest hardly receive 1.50 percent of the total, when in 1996 it was 1.79 percent. The income available monthly to 10 percent of the poorest homes was 26 percent less than in 1994, while for ten percent of the homes the reduction was 20 percent (González Amador and Castellanos, 2000). The coefficient of GINI for the monetary income in 1992 was 0.5086 , in 1994 it was 0.5137 , and in 2000 it was 0.4889 , which indicates a tendency in the concentration of the national wealth to decrease, though those with more however continues being high.

Quick economic growth has not resulted in an improvement in the levels of the population's standard of living, due to the inequitable distribution of income that impedes the transfer of macroeconomic benefits. The higher rates of growth that reached four percent, on the average, of the gross internal product between 1996 and 2000 have not contributed to improvements in the well-being and standard of living of the family, because they contribute 2.4 real percent of the product per layer. According to an analysis of El Financiero (2000), for each peso (Mexican currency) that was generated in the economy in the first trimester of the year, 0.07 cents corresponded the population with scarce resources (38.11 percent), while the population with high levels of revenue (10 percent) obtained 50 cents.

The political transition came harnessed to economic reform but there was not social advance. Cutting social expenditure in education and public health reduced the weight of bureaucracy gradually by transferring these functions from the State to the private sector. The governments' years in power leave behind "open wounds in the national conscience" from the indigenous conflicts of Chiapas. Social conflicts were sharply on the rise. The result being: increasing levels of poverty, the growth of the informal economy, increase in violence and public insecurity, corruption with impunity, the precarious conditions of micro, small and large enterprises and the 
deterioration of the countryside and farming sector. In sum, the current problem in Mexico is good macroeconomics but bad microeconomics.

Mexican government still has direct ownership over large state owned companies, some of which are monopolies, although it has little influence over the big business and industrial groups. The existing stockholders' ownership interest in a company is not diluted if the company sells debt to raise money in such a way that the investor will not become a co-owner. However, if the company sells equity allows the fund to become a co-owner thereby diluting (or decreasing) the existing stockholders' ownership interest in the company. A disadvantage of a debt investment is that the investor lacks interest on ownership and cannot have gains from an equity investment.

Many of the top firms belong to one of Mexico's business conglomerates or "groups". Garrido (1992:57) uses the term "big business" to refer to those people in positions of ownership and/or control over two or more conglomerates or groups. Business groups in México link together under a "single system of ownership a number of different enterprises, either within a single sector or across various sectors of the economy" (Thacker, 1998:7). Garrido (1992) reports that 99 in Mexico in 1989 counted almost 70 percent of the top 500 firms among their membership in that same year.

Many of these business conglomerates have separated ownership and management by placing control over management in a director-general who is not an owner or shareholder in the company (Salas-Porras 1992). Neoliberal governments have shown their inability to reduce the pain of the integration processes through more favorable negotiations that would allow comparative and competitive advantages for Mexico. The results of the globalization processes confirmed that it had gone in only one direction: the entrance of transnational and multinational enterprises, now called global enterprises or contemporary business, which in essence are foreign, have taken legal ownership of the natural resources, land, etc., and returned few benefits.

Private sector and business community challenged the legitimacy of the system itself and secured a permanent role in the political system in order to protect and promote their interests in the future. Private and public sectors differ in nature and specialization in their core competencies. A public sector investing its scarce resources in "loss-making, customer-unfriendly monopolies" is poorly equipped to perform the assigned functions and tasks (Savitsky and Burki, 1999). It has been argued that private or State monopoly creates a deadweight loss to the economy. The ultimate goal of the private sector was to play an active role in government sharing power as it was said by a prominent business leader:"we want to participate in the process of making decisions over the long-term" (Hernández Rodríguez 1986, 262). Under the "alliance for profits", business bargained and agreed to forsake a direct role in politics in exchange for the maintenance of a stable investment climate (Mizrahi 1992).

In this way, the factions integrated into the directing elite were recomposed of managers to guarantee the continuity of the economic model, the dimensioning of a functional democracy that matches the discipline of the market, and the structural reinvention of the system. The degree of market concentration in the main economic sectors and the existence of public and private monopolies is a feature that limits the competitiveness of Mexico's economic structure. The World Bank Mexico (2007) has argued that "in several key moments when government policies could have turned the structures of these sectors more open and thus competitive, the government's choice has tended to be to favor market concentration."

This allows a bigger reproduction of capital and deepening of the dominant instruments to markedly increase differences and social injustices. But this democracy favored by a authoritarian free market system is a hegemonic ideology of the elite of transnational globalized capitalism that imposes decisions to its own benefit. However the real power remains under the control of transnational capitalists.

The growing presence of "big business" leaders shows the existence of a small national nucleus of economic control across multiple sectors of the economy. The new business elite control the important business groups, by means of a system of interlocking management and boards of directors. Large business have separated ownership and management by placing control under a director general who is not an owner or shareholder in the company (Salas-Porras 1992). Garrido $(1992,57)$ refers the big business to those people in positions of ownership and/or control over two or more conglomerates or groups The actual number of people who control the top firms in Mexico is smaller due to overlapping networks of ties between the management of different groups spanning across several sectors of the economy.

The new government of Calderón's (2006-2012) main challenge will be to build new institutional structures to solve the problems of the new reality that faces the entrepreneurial and managerial group in power. For example, those institutions that impede the practice of monopoly and that sustain governance of the Mexican society. The proposed democratic capitalist model for market economy needs to be revised so that the function of the results 
is expressed in increments of poverty. Some of the main challenges for the rest of Calderón's administration are to recover the government's credibility and genuineness in such a way as to reduce the high index of poverty by creating one million two hundred thousand new jobs per year, and to maintain economic growth and development. Correction of social inequalities is required starting with the reorientation of economic policies. One inevitable topic is how to draft public policies that will combat inequality in education, health, infrastructure, and housing.

It is necessary that the State must govern and act to rectify inequality, create a social economy that is a humane economy, and humanistic policies in the economic sense with a high emphasis on combating inequality. Economic policies should be drafted to generate good conditions of human life and not only change the bias that gives the market an indisputable hegemony and to guide certain production bases, but to make the State responsible for combating inequality. Economic policies have to become unified to reduce poverty through such measures as the establishment of Social Banking to support families and associated companies, as well as to create a government salary pact between employer and worker, that allows workers to recover their purchasing power.

A political system is required that will produce a public administration that is accountable to the people in such a way that rulers are brought closer to those they govern and which will permit social participation in the design and implementation of public policy. However, the conservative panista speech manages only to recognize the social participation of private philanthropic non-governmental organizations. Nevertheless this joint alteration of party power, the civil society that had always maintained a relationship in conflict with a government that sought corporate control, now has the opportunity to participate in the design of the country in a new relationship with government.

\section{Results and Discussions}

Economic reforms of structural adjustment introduced in Mexico in the last two decades years have led to a mere ownership change of monopolies but did little to modify the regulatory framework The economic reforms introduced are leading to increased market concentration and have failed in strengthening the regulatory framework in the case of natural monopolies, in providing more opportunities to introduce competition and in enhancing the competitiveness of the economy as a whole. Market oriented reforms have yielded fewer results in terms of making Mexico more competitive (World Bank Mexico, 2007).

Transfers of asset ownership in key economic sectors such as land, airlines and telecom have lasting effects on the economic efficiency and on the distribution of political influence among economic actors. In this sense, privatization entails winners and losers. Privatizations in Mexico have favored new emerging large business. The newly rising class of entrepreneurs and enterprises emerged from the deals of the privatization program and the government protection that the deals themselves offered after the acquisition of the assets (Hoshino, 1996).

In the case of transition of the régime of the Mexican State: From the entrepreneurial State to a state of entrepreneurs, The change of political party in power within the same régime represented a rupture in the old Mexican political system and continuity of the processes of development according to the neoliberal pattern imposed by the interests of transnational capital. This way, the change became significant because it represented a final balance between a presidential régime and its neoliberal economic model. Salinas (1988-94) and Zedillo (1994-2000) truly represented the two big local groups of officials and entrepreneurs politically. The two technocratic presidents had as common governing characteristics a personal focus on social and power relationships. Both fostered the emergence of complicity between the technocrats and entrepreneurs enlarging the capital-politics relationship to the men that held economic power, without respecting the rules of the system or the correlation between social forces and politics.

The strategy they used to implement the neoliberal model consisted of maintaining a reduced group of technocrat economists in a network of alliances in collusion with capitalist groups. The institutional configuration of the Mexican state is reflected on the power of the presidency that cedes greater autonomy to policy makers augmenting the effect of government policies to forge winning political alliances with members of the private sector. These capitalist groups, those whom Ortíz Pinchetti (2000) named the nomenklatura, had insatiable financial interests and were the main beneficiaries of the model. In Salinas' strategy, through the support of PAN, political leverage was given to the group of entrepreneurs and financiers.

In the case of the privatization program in México, the winners are the small number of entrepreneurs who belong to the Mexican economic elite. Some economic elites gained advantageous positions during the decades of privileged access to Mexican State's power and government protection. A strong orientation toward the privatization program and regulatory framework attract flows of foreign direct forms of investment. The 
implementation of the privatization program in México has been very pragmatic: State-owned companies merged, closed outright, or were sold at token prices.

Privatization of public enterprises in México has been limited because of the restrictions on foreign investment in acquisition and participation, although the privatization program has been open to foreign investment which has purchased important assets. Despite the adoption of Washington consensus-type economic reforms, the results are not positive in terms of economic growth, social development and democratic governance. Privatization has failed to meet the objectives of achieving and economy with more efficient use of resources mainly because the lack of a set of incentives and regulatory frameworks to prevent the establishment of a private monopolies of what have been public monopolies.

The meltdown of the Mexican stock exchanges resulted in the loss of half of the stocks value and share prices, for major Mexican companies quoted on Wall Street, dropped 75 percent within a few months. However, after this situation was resolved a deeper crisis in financial markets came in the form of the devaluation of the peso and the sovereign-default crises. The majority of the governmental crises, without a degree of investment (as is the case of Mexico), were caused by characteristic weakness in governance. If local people and foreign investors fear the Mexican peso will be devalued, they may convert pesos into dollars.

The World Bank Mexico (2007) argues that "the Mexican elite has benefited from restrictions on foreign entry into privatized sector", but while in a number of Latin American countries, privatization has been associated with the entry of foreign capital, by contrast "only five privatizations were carried out with the participation of foreign investors. The majority of subscribed capital across the privatization program was therefore provided by Mexican investors".

The losers are the immense urban poor people, peasants, landless rural and small proprietors of land, workers, general consumers, owners of micro, small and medium size firms that have to absorb higher prices and higher input costs. Privatization has failed to meet the objectives of achieving and economy with more efficient use of resources mainly because the lack of a set of incentives and regulatory frameworks to prevent the establishment of a private monopolies of what have been public monopolies. Nowadays, Mexican economy is dominated by a network of private monopolies with a governance linked trough cross-shareholdings.

The way that the privatization and trade liberalization reforms were conducted in Mexico, according to the World Bank Mexico (2007:68) suggests "that strong business influence on politics continues, albeit with some changes in the identities of the elites involved and the form of the interactions between the state and businesses. The clear tendency of wealth concentration and unequal distribution of economic benefits (and of the corresponding political influence) has created a highly unequal political playing field where a small number of well-endowed and well-connected business elites manage to obtain preferential concessions from the government (typically in the form of market protection)".

\section{Refrences}

Agénor, Pierre-Richard. (2001). "Benefits and Costs of International Financial Integration: Theory and Facts," Policy Research Working Paper \#2699, Washington, DC: World Bank, September 7.

Americas Watch. (1993). "Mexico" Americas Watch, New York and Washington D.C., Vol. V, No. 10, October, p. 12.

Arriola, Carlos, with the assistance of Rafael Martí. (1994). Documentos básico: Tratado de Libre Comercio de América del Norte. México, D.F.: SECOFI.

Blanco Mendoza, Herminio. (1994). Las negociaciones comerciales de México con el mundo. México, D.F.: Fondo de Cultura Económica.

Bazdresch P., Carlos and Carlos Elizondo. (1993). "Privatization: The Mexican case" in Latin America: Privatization, property rights, and deregulation I, ed. Werner Baer and Michael E. Conroy. Quarterly Review of Economics and Finance 33(special issue):45-66.

Becerril, Isabel. (2000). "Gobierno foxista, amigable, pero mantendremos la distancia: Coparmex", El Financiero, 15 de Septiembre.

Corona, R. (1993) "Mexico Rewrites the Rules." Hemisfile. San Diego: Institute of the Americas.

Crummet, Maria de los Angeles. (2001). "A gendered economic history of rural households: Calvillo, Aguascalientes, México, 1982-1991” Frontiers. 
Crystal, Jennifer S., B. Gerard Dages, and Linda S. Goldberg. (2002). "Has Foreign Bank Entry Led to Sounder Banks in Latin America?" Current Issues in Economics and Finance, Federal Reserve Bank of New York, Volume 8, Number 1, January 2002.

Davis, Diane E. (1992). "The politics of economic liberalization in Mexico: Explaining the North American Free Trade Agreement". Paper prepared for the 1992 American Sociological Association Annual Meetings, Pittsburgh, PA, August 20-23.

Dymski, Gary A. (2002). The Global Bank Merger Wave: Implications for Developing Countries. Department of Economics. University of California, Riverside. Riverside CA 92521 USA.

El Financiero. (2000). "Capta la población de bajos recursos 0.07 centavos de cada peso del PIB”. El Financiero, 15 de septiembre de.

Elizondo, Carlos. (1993). The making of a new alliance: The privatization of the banks in Mexico. Documento de Trabajo 5, Estudios Políticos. México, D.F.: Centro de Investigación y Docencia Económicas.

Fazio, Carlos. (2000a). "En gestación, un nuevo poder: la meta, el Estado empresarial”, La jornada, sábado 26 de agosto.

Fazio, Carlos. (2000b). "Fox, el primer presidente empresario", La Jornada, lunes 28 de Agosto, página 18.

Garrido N., Celso. (1993). "Los grupos privados nacionales en México."Reporte de Investigación No. 156, Serie II. México, D.F.: Universidad.

Garrido N., Celso. (1992). La evolucíon del actor empresarial mexicano en los ochentas. Proyecto Organizaciones Empresariales en México, Cuadernos 4. Facultad de Ciencias Políticas y Sociales, Instituto de Investigaciones Sociales. México, D.F.: Universidad Nacional Autónoma de México. Autónoma Metropolitana, Unidad Azcapotzalco.

Grier, Robin M. And Grier Kevin B. (2000). "Political cycles in nontraditional settings: theory and evidence from the case of Mexico", The Journal of Law and Economics, Volume XLIII (1), April 2000. Pages 239-263.

González Amador, Roberto y Castellanos, Antonio. (2000). "El crecimiento causó concentración de la riqueza y más pobres: Boltvinik", La Jornada, Lunes 21 de Agosto.

González Anaya, José Antonio, and Marrufo, Grecia M. (2001). "Financial Market Performance in Mexico." Paper prepared for the Mexican Credit Conference, October 5-6, 2001. http://scid.stanford.edu/events/Mexican_Credit/gonzalez.pdf

Haber, Stephen. (2005). "Why Institutions Matter: Banking and Economic Development in Mexico." http://www.stanford.edu/ haber/papers/Haber_WhyInstitutionsMatter_June2005.pdf

Hernández Rodríguez, Rogelio. (1986). "La política y los empresarios después de la nacionalización bancaria". Foro Internacional 27(2): 247-265.

Hoshino, Taeko. (1996). "Privatization of Mexico's Public Enterprises and the Restructuring of the Private Sector." The Developing Economies 34(1): 34-60.

Jiménez, Eva. (2000). "El presidente que no quería ser”, El Financiero, Sábado 2 de Septiembre, página 13.

Lewis, Jessa (2002). "Agrarian Change and Privatization of Ejido Land in Northern Mexico", Journal of Agrarian Change 2 (3), 401-419.

Luers, A.L. (2003). From Theory to Practice; Vulnerability Analysis in the Yaqui Valley Region of Sonora, Mexico. Stanford University Ph.D. Dissertation Thesis.

Maxfield, Sylvia. (1990). Governing capital: International finance and Mexican politics. Ithaca: Cornell University Press.

Maxfield, Sylvia. (1989). "International economic opening and government-business relations" In Mexico's alternative political futures, ed. Wayne Cornelius, Judith Gentleman and Peter H. Smith, 215-236. Monograph Series, 30, Center for U.S.-Mexican Studies, University of California, San Diego.

Mehta, Stephanie. (2007). "Carlos Slim the richest man in the world", Fortune, August 20, 2007.

Murillo, Maria Victoria. (2001). "Conviction versus Necessity: Public Utility Privatization in Argentina, Chile and Mexico." Paper prepared for the $97^{\text {th }}$ Annual Meeting for the American Political Science Association, SanFrancisco.

Ortíz Pinchetti, José Agustín. (2000). “Informe final.”. La Jornada. Domingo 3 de Septiembre. 
Randolph, R. Sean. (1994). Economic reform and private sector development in Russia and Mexico. The Cato Journal, Vol. 14 No 1, Spring/Summer.

Mehta, Stephanie, N. (2007). Carlos Slim, the richest man in the world, Available: http://money.cnn.com/2007/08/03/news/international/carlosslim.fortune

Mizrahi, Yemile. 1992. La nueva oposición conservadora en México: La radicalización política de los empresarios norteños. Foro Internacional 32(5): 744-771.

Nayyar, Deepak, (2006). Development through Globalization?, Centre for Economic Studies and Planning, School of Social Sciences, Jawaharlal Nehru University, New Delhi, UNU-WIDER 2006

Salas-Porras, Alejandra. (1992). "Globalización y proceso corporativo de los grandes grupos económicos en México". Revista Mexicana de Sociología 54(2): 133-162.

Savitsky, Joseph J. and Burki, Shahid Javed. (1999). "Capital Flows to Emerging Markets and Policy Implications:The Experience of Latin America and the Caribbean", The Japan Program's Working Paper Series on Globalization. EMP Financial Advisors, LLC contracted by the Inter-American Development Bank.

Schulz, Donald E.; Wager, Stephen J. (1995). "Civil - military relations in Mexico: the Zapatista revolt and its implications", Journal of Interamerican Studies and World Affairs, Spring 1995 v37 n1.

Shields, David. (2005). PEMEX: La Reforma Petrolera. México, DF: Editorial Planeta.

Thacker, Strom C. (1998). "Big business, the state, and free trade in Mexico: Interests, structure, and political access". Department of International Relations, Boston University. Prepared for delivery at the 1998 meeting of the Latin American Studies Association, The Palmer House Hilton Hotel, Chicago, Illinois, September 24-26, 1998.

World Bank Mexico. (2007). Democratic governance in Mexico: Beyond state capture and social polarization 2007 by The International Bank for Reconstruction and Development / The World Bank. 1818 H Street, N.W. Washington, D.C. 20433, U.S.A. Internet: www.worldbank.org.mx

Vega Cánovas, Gustavo F. (1991). Bilateral or plurilateral free trade in North America: Economic and political implications for Mexico. Ph.D. diss., Yale University.

Table 1. Presidents of México, supporting political party and presidential terms

\begin{tabular}{|l|l|l|}
\hline President & Political party & Presidential terms \\
\hline 'José López Portillo & $\begin{array}{l}\text { Revolutionary Institutional } \\
\text { Party (PRI) }\end{array}$ & $1976-1988$ \\
\hline Miguel de la Madrid Hurtado & $\begin{array}{l}\text { Revolutionary Institutional } \\
\text { Party (PRI) }\end{array}$ & $1982-1988$ \\
\hline Carlos Salinas de Gortari & $\begin{array}{l}\text { Revolutionary Institutional } \\
\text { Party (PRI) }\end{array}$ & $1988-1994$ \\
\hline $\begin{array}{l}\text { Ernesto Zedillo Ponce de } \\
\text { León }\end{array}$ & $\begin{array}{l}\text { Revolutionary Instituional } \\
\text { Party (PRI) }\end{array}$ & $1994-2000$ \\
\hline Vicente Fox Quezada & National Action Party (PAN) & $2000-2006$ \\
\hline Felipe Calderón Hinojosa & National Action Party (PAN) & $2006-2012$ \\
\hline
\end{tabular}

